\title{
CULTIVATING JUST PLANNING AND LEGAL INSTITUTIONS: A CRITICAL ASSESSMENT OF THE SOUTH CENTRAL FARM STRUGGLE IN LOS ANGELES
}

\author{
CLARA IRAZÁBAL \\ Columbia University \\ ANITA PUNJA \\ University of Southern California
}

\begin{abstract}
The South Central Farm (SCF) in Los Angeles was a 14-acre urban farm in one of the highest concentrations of impoverished residents in the county. It was destroyed in July 2006. This article analyzes its epic as a landscape of resistance to discriminatory legal and planning practices. It then presents its creation and maintenance as an issue of environmental justice, and argues that there was a substantive rationale on the basis of environmental justice and planning ethics that should have provided sufficient grounds for the city to prevent its dismantling. Based on qualitative case study methodology, the study contributes to the formulation of creation and preservation rationales for community gardens and other "commons" threatened by eventual dismantlement in capitalist societies.
\end{abstract}

\footnotetext{
"Ah, mi'jita," she says at last. Her eyes are shining. "You have found out the secret of our journeys."

"What secret, Tía?"

"Que las flores siempre ganan. The flowers always win."

Patricia Preciado Martin, “The Journey” (1980). ${ }^{1}$
}

T

he South Central Farm (SCF) in South Los Angeles (LA), ${ }^{2}$ California, was a 14-acre urban farm divided into over 350 family-maintained plots that grew an extensive variety of produce and medicinal plants unique to the region. The families, mainly Latina/o and many unauthorized immigrants, were originally allotted these "survival gardens" by the Los Angeles Regional Foodbank, and had incomes no greater than $150 \%$ of the poverty level in the region. ${ }^{3}$ Most used the food and medicinal plants to augment their dietary and health care needs, and it is estimated that some 2,000 people directly benefited from the farm, as each plot was managed by a family of four members or more. Bound by industrial areas to the north, east, and south, the

Direct Correspondence to: Clara Irazábal, Graduate School of Architecture, Planning and Preservation at Columbia University, 1172 Amsterdam Avenue, New York, NY 10027. E-mail: irazabal.zurita@columbia.edu.

JOURNAL OF URBAN AFFAIRS, Volume 31, Number 1, pages 1-23.

Copyright $@ 2009$ Urban Affairs Association

All rights of reproduction in any form reserved.

ISSN: 0735-2166. 


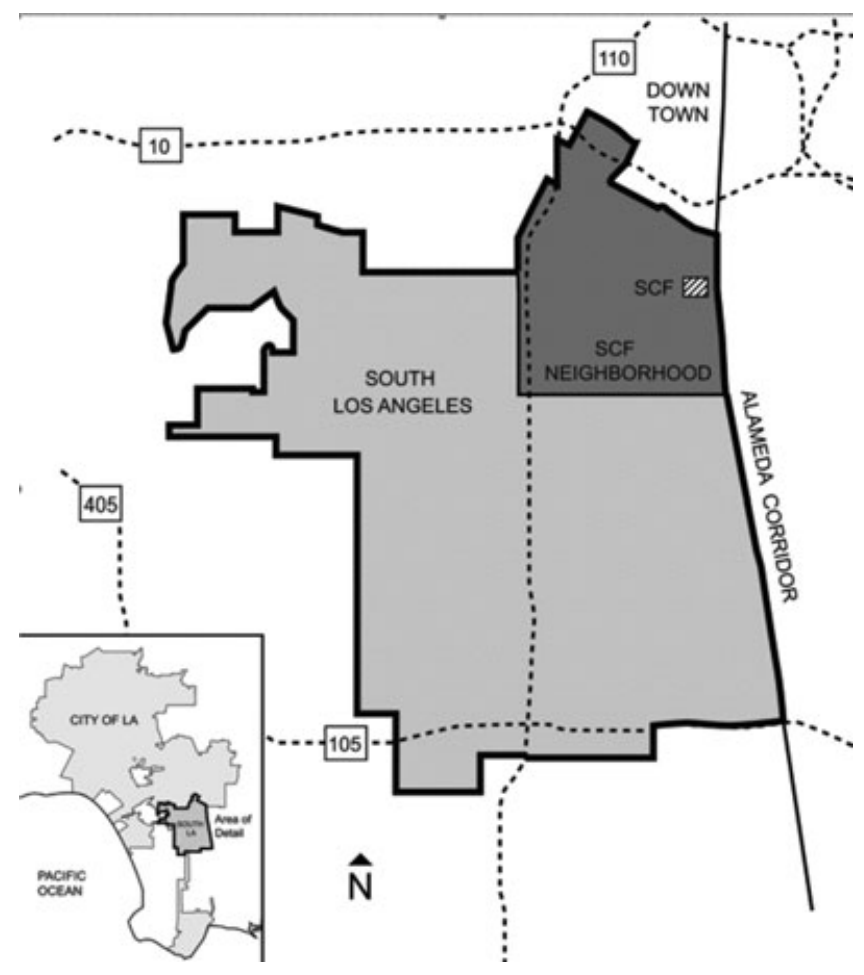

FIGURE 1

SCF Site and Neighborhood in Context of South Los Angeles

majority-Latina/o neighborhood to the west of the Alameda and 41st Street farm had one of the highest concentrations of impoverished residents countywide. The area is also a place that has experienced a rapid demographic transition from majority African American to majority Latino in the last few decades. Figure 1 illustrates the SCF neighborhood and SCF site in the context of South LA. Figure 2 shows the percentage change in Latina/o population within census tracts surrounding the SCF site between the years 1980 and $2000 .^{4}$

On July 5, 2006, fourteen years of work at this urban community garden, the largest in the United States, were bulldozed. This article analyzes the epic of the SCF-which was entrenched in a prolonged and intense legal battle for its preservation and continues to be for its recreation-as an immigrant landscape of resistance to discriminatory governance institutions, most especially legal and planning practices in Los Angeles. This article is divided into three sections. The first section presents the creation and maintenance of the SCF as an issue of environmental justice, and examines community gardens' impact on neighborhood improvements in physical and quality-of-life conditions that alleviate poverty. It then analyzes the actual impact of improvements in those conditions in South LA as a result of the SCF. The article argues that no matter what the change produced by the garden in South LA had ultimately been, there was a substantive rationale, on the basis of environmental justice and planning ethics, that should have provided sufficient grounds for the city to prevent the dismantling of the farm. Planning scholars and practitioners are relatively familiar with the use of civil rights and community economic development frameworks for the analysis of matters related to equity planning. This article proposes to enrich the analytical toolkit of planners by offering the complementary frameworks of 


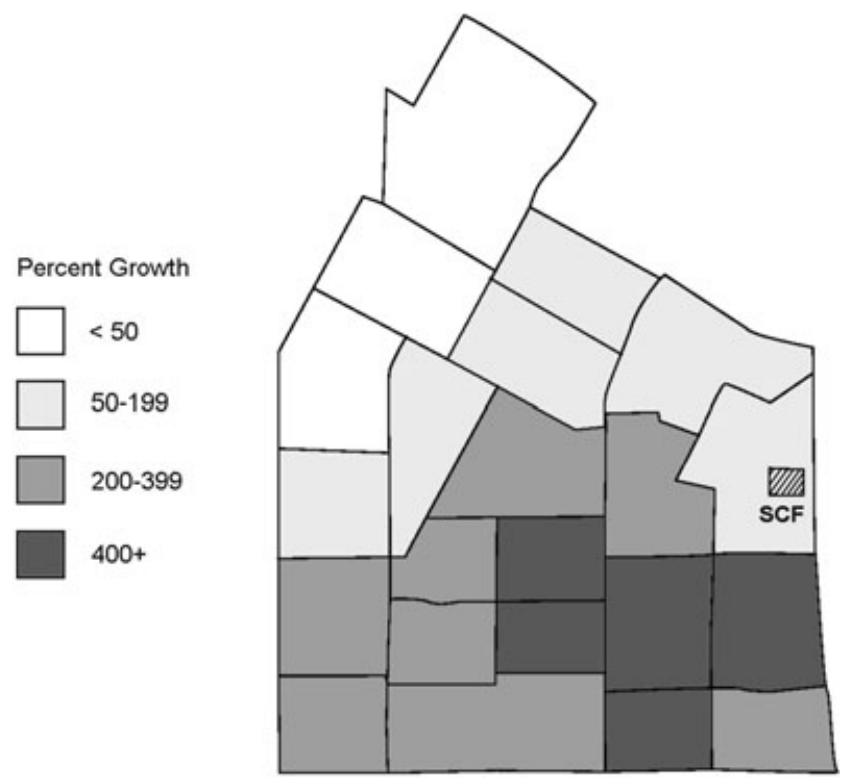

\section{FIGURE 2}

Growth of Latina/o Population in SCF Neighborhood, 1980-2000

critical legal studies and environmental justice for such analyses. This broadened analytical scope enhances understanding of both the nuanced cultural factors of disenfranchised groups beyond matters of socioeconomic class (including ethnicity, gender, age, religious affiliation, sexual preference, origin, body capacity, etc.) and the spatial specificities of planning for the advancement of equity.

The second section elaborates on the legal arguments and procedural circumstances both for and against the farmers throughout the struggle for the garden, and analyzes them in light of structural legal biases against minorities and the poor, the tensions between use and exchange values, and the right to the just city. Finally, the third section discusses the significance of the SCF to the future of the environmental justice and urban gardening movements and, ultimately, our cities. By combining environmental concerns and social and racial justice in a single, visible project - an urban farm-leaders such as the South Central Farmers may be recognized as having greater mobilizing and interethnic, interclass coalitional potential than Smart Growth, New Urbanist, or New Regionalist advocates. More critically, the SCF case demonstrates that while white middle-class suburbanites should strive to expand inclusion of non-white lower-income urbanites in smart growth or regionalist coalitions, they should also understand and respond to the latter's own initiated calls for solidarity and leadership toward different conceptions of fairer regional growth models. Notably, in the case of the SCF, it was the SC Farmers, representing non-white lower-income urbanites, who were heading the regional, and even international, call for environmental justice. Thus, the SC Farmers signal the growth of minority-in this case Latina/o - environmental justice activism, a movement identified as a "greening" of minority/Latino politics, or inversely a "browning" of environmentalism (George, 2006). The arguments presented here contribute to the formulation of creation and preservation rationales for community gardens and other "commons" threatened by eventual dismantlement in the United States and other 
capitalist societies. Thus, the work offers conceptual frameworks to policy makers and the legal and planning professions to further opportunities to attain more environmentally and socially equitable cities.

Based on qualitative case study methodology, whereby the research involved sustained interaction for more than a year with the people being studied, in their own language and on their own turf (Yin, 2002), the project employs a triangulation of literature review, participant observation, and active interviews. The objectivity of qualitative research such as this benefits from the reliability and validity of its observations on culture (Kirk \& Miller, 1985), and is complemented here with spatial demographic analysis of South LA and empirical quantitative analysis of comparable cases of urban farms elsewhere in the nation. Our qualitative approaches included a mixture of naturalistic, holistic, ethnographic, phenomenological, and biographic research methods (Stake, 1995). Following Feldman (1994), we used three key interpreting strategies for dealing with qualitative data: ethnomethodology, semiotics, and deconstruction. We obtained, categorized, and analyzed different media documents, including not only traditional primary documents such as newspapers and magazines, but also such contemporary forms as television newscasts and cyberspace (Altheide, 1996). Transcending the assumption of expertise of the interviewer in traditional methods, our "active interview" method (Holstein \& Gubrium, 1995) considered our interviewees as equal partners in constructing meaning through interviews. This had consequences on the conception of the sample (more open ended, with the inclusion of more subjects traditionally considered disenfranchised by their contribution to the production of mainstream knowledge and their participation in legal or formal decision making), on the ways in which the interviews were conducted (less structured, more flexible, opened to a two-way dialogue and to an offering of solidaristic and reciprocal friendship), and on the results (our reflections were shared with interviewees when possible for their approval). The interviews and the reflections derived from them thus informed the nuanced product of both parties.

\section{The (Mis)behavior of the Law}

The SCF's convoluted story (discussed below) is revelatory of the values and power struggles in Los Angeles and the nation at large. This section analyzes the legal arguments and procedural circumstances in favor of and against the farmers in light of structural legal biases against minorities and the poor, the tensions between use and exchange values, and the right to the just city. While many legal sociologists acknowledge the racial and cultural biases of the legal system, they do not question the just intent of the system itself. Other scholars, however, posit that the legal system itself is an ideology to advance the economic self-interest of the capitalist class (Black, 1977; Tigar, 2000). A strand of critical social theory states that the application of the law varies according to the sociospatial aspects of the litigants; that is, the law usually "behaves" differently than its jurisprudential principles alone dictate, and as such, becomes itself a tool of social and economic oppression. Donald Black (1977) described the extent to which the law "behaves" according to complex strata of the social, economic, and cultural conditions of litigants. His work provides a theoretical basis for understanding the legal context in which the SCF struggle takes place. This theoretical framework, Baumgartner later elaborates, forms the "sociology of law, which locates the source of legal variation in the social environments within which legal environments occur... shift[ing] the focus from doctrinal and technical elements of cases to social ones" $(1999$, p. 5). In sum, Black's theory states that the harshest and most penal law (vs. the more benign conciliatory law) behaves according to five parameters (p. 12): social stratification, occurring most when low-status persons (or organizations) offend superiors; social morphology, occurring most when marginalized persons offend more integrated persons; cultural centrality, occurring most when a cultural minority offends a member of the established 
culture; organization, occurring most when individuals offend organizations; and social control, occurring most when people of poor reputation offend those of highly esteemed reputation.

In addition, space, particularly as conceived by land-use law, is a fertile terrain where oftentimes social elements prevail over the doctrinal and technical aspects of the law. For instance, Heynen, Perkins, and Roy (2006) explain the unevenness of urban green space in Milwaukee as a result of the political ecology of property relations within capitalist societies and its differential treatment of racial and ethnic groups. Mitchell (2003, p. 793), based on Gilmore (2004), comments that relations of property

are themselves deeply entwined in all manners of other relations, from race and gender to class and power, and ... the law-landscape nexus is one through which what she calls 'breathtakingly cruel shifts in the meaning and practice of justice' are made concrete. This landscape of injustice, logical as it is in terms of crisis-laden capital flows, is a key component of society's 'degeneration' (as Bunge, 2001 calls it).

Significantly, Tigar (1977) notes the symbiotic codependence of bourgeois ascendancy and the contemporary legal framework. Under this lens, the SCF constituted a case of further bourgeois ascendancy at the expense of poor immigrants of color in Los Angeles. Under the biased legal system that acted to ignore or delegitimize the farmers and their claims, and in an economic system which the laws were created to protect, the SC Farmers found themselves like many other marginalized social movements-disenfranchised by the law and unable to find effective political tactics under such conditions. In effect, the case of the SCF is a superlative case study of Black's theory that applications of law vary across social space. The farmers, who comprised a "low-status," marginalized cultural minority of poor reputation, found themselves pitted against an elite millionaire developer sure-footed in the establishment. Thus, regardless of the validity of the farmers' legal claims to the land, they found themselves at a socially constructed disadvantage from the get-go in the American legal system by virtue of the sociocultural characteristics that identify them. At the opposite end of the social spectrum, the landowner was also questionably treated by the legal institutions, although in his case it was to favor him. Horowitz, the developer that was ultimately granted the land, had been rightly compensated at the assessed market value in the 1980s for the site, greatly weakening his claim for first consideration in the buyback of the site, especially at the expense of the farmers who had occupied and worked the land over 14 years. Furthermore, there was a combination of other factors regarding the buyback that indicated advantageous treatment of the developer, including the below-market-value purchase price Horowitz paid for the site, the questionable legality of the city selling property that belonged to another agency (the Harbor Department), and the settlement of the case out of court without required public notice or participation.

Critical Legal Studies (CLS) is a framework that offers further analysis on the uneven application of law in the SCF case. CLS thought not only criticizes the rules and outcomes of particular legal rulings, but also the larger structures of conventional legal thought and practice that facilitate the rulings, positing that the wealthy and powerful use prevailing legal doctrines and conceptions in order to maintain power. This allows legitimization of injustice under the guise of "neutral and objective treatment," ultimately, "shielding structures of power from fundamental reconsideration" (Harvard Bridge Project, n.d.). Throughout the legal contestation of the SCF case, powerful actors took the opportunity to use legal decisions as justification to dismiss the validity of the SCF and its supporters, at times completely misinterpreting the facts to do so. When the Los Angeles Times reflected on the transfer of property from the city (public domain) back into Horowitz's private hands, they rejected the validity of the farmers legal claim on the land by stating that "the bottom line is that the courts ruled for Horowitz." In actuality, the case was 
decided in an out-of-court settlement between Horowitz and City Attorney Delgadillo. However, those in positions in power not only influence legal outcomes, but also the framing of history as well, leaving groups such as the SC Farmers doubly vulnerable to injustice at the hands of the law.

Such inconsistencies in the application of the law provide an apt example of why CLS theorists believe that law is politics (Cornell Law School, 2006) — created by “ideological struggles among social factions in which competing conceptions of justice, goodness, and social and political life get compromised, truncated, vitiated, and adjusted" (Altman, 1986, p. 221). These "competing conceptions" form the basis of their belief in "legal indeterminacy," a denial of the existence of one correct outcome in any legal case. CLS theorists posit that this leads to a "profound inconsistency" that "permeates the deepest layer of the law," allowing a judge to justify any number of conflicting outcomes, and undercutting liberal conceptions regarding the existence of a legitimate source of lawmaking authority (Adelman \& Foster, n.d.). Significantly, others examine the spatial results of an oppressive legal order and the way it links to racial hierarchy, for instance in the segregation of our metropolitan areas into "privately segregated, publicly protected enclaves" (Ford, 1999).

\section{The Right to the Just City}

The case of the SCF is not isolated. Urban elites frequently implement mechanisms that effectively prevent or control the spatial practices of "others" that deviate from the ethos of a "consumerist citizenship." They do so, for instance, through the privatization of open space, the criminalizing of immigrants and the poor, and the disciplining of insurgent groups (MacLeod, n.d.). These trends are so commonplace and unapologetically pursued in some cities that Mitchell has called this the era of the "post-justice city" (Mitchell, 2001), in which citizenship rights are taken away from the ones who cannot partake in the neoliberal economy (Irazábal, 2008; Miraftab \& Wills, 2005; Miraftab, 2004). Amid these global trends, the SCF was evidence of a counterspace, community, and process providing residents of Los Angeles an affordable and reproducible model to emulate in the ever-more-difficult quest for the just city (Irazábal, 2006; Fainstein, 2000).

Henri Lefebvre's $(1968,1996)$ seminal work on "the right to the City" refers to the rights to inhabit and make use of the city and "the right to have rights" regardless of one's legal status. Purcell has carefully analyzed the concept's transformative potential, invoked here:

Lefebvre offers a radical... vision that entirely upends the social relationships that currently govern urban politics. He argues that urban inhabitants, rather than capital interests and the state, should take a direct and central role in making the decisions that produce urban space.... He insists that decision-making about urban space should be guided by the principle that use value should always trump exchange value - that above all other considerations urban space should be produced to meet the everyday needs of those who inhabit it (Purcell, 2005, p. 200).

....Lefebvre interrogates and rethinks the decision-making structures that produce the city, and so introduces a much more radical democratization of the city ... not just the right to speak in public space, but to decide the geography of public space; not just the right to be housed, but to decide the geography of affordable housing (ibid, p. 201).

Thus, the right to the city must be seen "as an opening to a new urban politics" (Purcell, 2002, p. 99). In Harvey's words, the right to the city should not be "merely a right of access to what the property speculators and state planners define, but an active right to make the city different, to shape it more in accord with our heart's desire, and to re-make ourselves thereby in a different 
image" (2003, p. 940). Defending the SCF, the farmers and their allies-and with them and through them many in the community of Los Angeles-were pushing for the expansion of their rights to the just city. However, the democratic and liberating use value of this space contrasted with the exchange and symbolic values of private property that prevailed in the legal deliberations about this case. Ultimately, the SCF controversy exposed questionable priorities and procedural practices within LA City Hall. If the city had exercised eminent domain in the 1980s with the intent to build an incinerator in the site, why did it not do it to protect a farm 14 years after? "Surely, growing food is as much in the public interest as burning trash," expressed a sympathetic commentator (Mark, 2006).

\section{SCF: A PLANNING ETHICS CONUNDRUM}

This section examines SCF in the context of the environmental justice (EJ) movement, and subsequently looks at the impact community gardens can have on neighborhoods in regards to physical and quality-of-life conditions that alleviate poverty. It also analyzes the actual impact of improvements on those conditions in South LA as a result of the SCF garden. More significantly, it argues that no matter what the change in the South LA area had ultimately been, there was in all cases a substantive rationale on the basis of environmental justice and planning ethics to prevent the city from dismantling the garden.

\section{The SCF as an Issue of Environmental Justice}

As the standard in this analysis, we use the U.S. Environmental Protection Agency's definition of environmental justice as the

fair treatment and meaningful involvement of all people regardless of race, color, national origin, or income with respect to the development, implementation, and enforcement of environmental laws, regulations and policies. Fair treatment means that no group of people-including racial, ethnic, or socioeconomic groups-should bear a disproportionate share of the negative environmental consequences resulting from industrial, municipal, and commercial operations or the execution of federal, state, local, and tribal programs and policies (U.S. EPA, 1998, p. 1).

Originally a reaction to the siting of hazardous facilities in minority neighborhoods, the EJ movement has grown and diversified markedly in recent decades to encompass "the adoption of a broad notion of the environment that includes a critique of the very nature of our contemporary urban form of sprawling suburbs and struggling cities, and how this shapes opportunity" (Pastor et al., 2006, pp. 8-9). The EJ movement aims for environmental injustices to be rapidly redressed through targeted action and resources: "targeting resources where environmental and health problems are greatest and social resilience may be lowest - that is, poorer and more minority communities - is simple common sense" (Bullard, 1994, pp. 237-266; Pastor, Gallegos, \& Prichard, 2005). EJ also insists that those who are most affected by the environmental decisions should have a central voice in the regulatory process. Thus, there is a heavy emphasis on community participation, neighborhood autonomy, and democratic decision making (Pastor et al., 2006, pp. 7-8).

Low-income people and communities of color, however, are systematically disadvantaged in the political decision-making process (Pulido, 2000). For instance, Heynen et al. (2006) discuss the impact of political economy on race and ethnicity in producing environmental inequality. It 
is well established that minorities are likely to bear greater health and environmental risks in their neighborhoods (Curtis, 2004; Day, 2006; Institute of Medicine, 1999; Spielman et al., 2006; Squires \& Kubrin, 2006). Racial segregation further solidifies disparities in socioeconomic status and widens the unequal distribution of access to jobs, education, public services, culture, safety, health, transportation, and amenities such as parks and green space (Bullard, Johnson, \& Torres, 2000; Dreier, Mollenkoph, \& Swanstrom, 2001).

Racial and class disparities in these regards are particularly severe in Los Angeles (Pulido, 2000; Morello-Frosch, Pastor, \& Sadd, 2001). The city is one of the most polluted and the most "park-poor" big cities in America. It has fewer acres of accessible parks per person than any major U.S. city, with the gravest conditions occurring in poor neighborhoods. Only 30\% of Angelenos live within a quarter mile of a park, compared with between $80 \%$ and $90 \%$ in Boston and New York. Two thirds of LA's children, more than 700,000, do not live within walking distance of a park (Villaraigosa, 2005). A recent study of park space in Los Angeles County found that the South LA subregion ranked lowest in regards to park access of all Los Angeles subregions examined, at 1.2 park acres per 1,000 residents; in marked contrast to the 59.1 acres per 1,000 residents found in West LA, a wealthier part of the city (Sister et al., 2007).

Regarding food access and choice, which urban farms expand for their beneficiaries, studies have shown that there are fewer supermarkets per capita in neighborhoods with predominately low-income, minority, or immigrant residents. In Los Angeles, a "grocery gap" persists despite the pledges of retail companies following the 1992 rebellion $^{5}$ to build more markets in depressed neighborhoods, with one supermarket for every 42,000 people within a 52-square mile area affected by the unrest, as compared to one supermarket for every 24,000 in LA County as a whole (Shaffer \& Gottlieb, 2002). In addition, low-income consumers were less likely to possess automobiles, further limiting their access to food choices (Cotteril \& Franklin, 1995, cited in Prevention Institute for the Center for Health Improvement, 2002). The lack of physical, financial, and mental access to healthy food in these poor neighborhoods has prompted some to call them "food deserts" (Mari Gallagher Research \& Consulting Group, 2006, 2007a, 2007b). Paradoxically, even urban gardens, well suited to address this food insecurity, are inequitably distributed. In 2003, only around 10 out of 62 official community gardens in the LA region were located in underprivileged areas (Gottlieb, 2006b).

The EJ framework raises difficult ethical questions when urban burdens are systematically distributed inequitably along characteristics such as race, national origin, and/or income (Squires \& Kubrin, 2006). To really develop its potential as an analytical tool and as an instrument for the expansion of equitable development, there is significant need for the expansion of research that links EJ and the legal regimes that produce it, prevent it, or otherwise (de)construct it. Peña (2003, p. 62) rightfully points out that the EJ movement is still a "legal misfit ... at the theoretically undeveloped intersections of environmental and civil right law." According to Pastor et al., "[u]nderstanding this broader pattern and suggesting how ongoing environmental policy could minimize differential risks would be a major contribution to the public debate" (Pastor et al., 2006, p. 40). It is at this intersection of EJ with race, income, and other social characteristics that analysis of the SCF is particularly illuminating.

Taking these arguments into consideration, we posit that no matter what the change produced by the urban farm in South LA had ultimately been-whether conditions in this neighborhood had worsened, remained the same, or improved substantially by 2006 as a result of this garden created in 1992 - there was in all cases a substantive rationale on the basis of environmental justice and planning ethics that should have provided sufficient grounds for the city to prevent the dismantling of the farm. With this case, the city was thus placed in an ethical conundrum. If the conditions of environmental injustice in this neighborhood had worsened, remained the same, or not improved substantially after 14 years of the farm's existence in 2006, then the 
City's rationale in 1992 for the granting of this land to the community-namely, to improve neighborhood conditions after the civil unrest, redress environmental injustice, and improve city relations with the community-would still hold. Thus, it would have been ethically questionable to strip the community of the farm. If, on the other hand, the conditions of environmental justice in this community had improved substantially by 2006 and if the existence of the community garden were proven to have constituted a significant cause in that positive trend (as was the case, as explained below), then the city had been successful in partially redressing environmental injustices in the community through its allocation of this land to farm use. Such conditions should therefore have prevented the city from dismantling the farm, lest the physical and quality-of-life improvements gained in the community be lost.

\section{Community Gardens' Impact on Neighborhoods' Improvements in Physical and Quality-of-Life Conditions}

The following subsections provide evidence of the multidimensional benefits of community gardens on neighborhoods' physical and quality-of-life conditions, and explain how the SCF surpassed the average community garden's benefits in South LA. Advocates of gardens offer many arguments about the positive aspects of community gardens. However, until recently, knowledge on the impact of community gardens on surrounding neighborhoods was limited and mostly drawn from qualitative observations. Our qualitative fieldwork on the SCF supports claims that gardens, besides increasing the value of adjacent properties and being a catalyst for neighborhood revitalization, provide stabilization for neighborhoods, are cheap alternatives to city parks, create venues for community organizing and networking, supply fresh food in areas that lack proper access to grocery stores, and offer opportunities for exercise and therapy for residents (Been \& Voicu, 2006, p. 3). Other testimonials and studies account for the benefits of less crime (Kuo \& Sullivan, 2001), better property maintenance and values, fewer abandoned buildings, greater rates of home ownership, adaptive reuse of vacant lots, cleansing of brownfields, development of leadership and technical skills, air purification, control of noise and temperature, creation and preservation of fauna and flora habitats, and improvements in sense of community and place (Tranel \& Handlin, 2006).

Recently, several major quantitative studies have shed complementary light on this matter, which offer substantive guidance to public policy efforts (Been \& Voicu, 2006; Tranel \& Handlin, 2006). Been and Voicu devised a study that disentangled the specific effects of 636 community gardens from other changes happening in neighborhoods and properties in New York City over several decades (1977-2000s), finding that "the opening of a community garden has a statistically significant positive impact on residential properties within 1000 feet of the garden, and that the impact increases over time," and furthermore, "that gardens have the greatest impact in the most disadvantaged neighborhoods" (2006, p. 2). Significantly, they also estimated that "the [overall] benefits generated in the 1000-foot ring [around community gardens] total almost $\$ 1.5$ billions (in 2003 dollars) — or $\$ 2.3$ million per garden," considering only the increments of the first 5 years after garden establishment (ibid, p. 28). Relating specifically to tax revenue gains, they stipulated that:

The City [of New York] gross tax benefit generated by all community gardens over a 20-year period amounts to about $\$ 563$ million. Under the scenario in which the local government would have fully subsidized the garden provision [which was not the case], the City's total investment would have amounted to about $\$ 83.5$ million. Thus, the estimated net tax benefit would be, in the aggregate, about $\$ 480$ million or, per garden, over $\$ 750,000$ (2006, p. 28). 
In addition, the presence of greenery in an area has been shown to have positive effects on property values. For instance, the effect of greenery on sales of homes in an inner Los Angeles neighborhood with no park over an 18-month period revealed that "an $11 \%$ increase in the amount of greenery (equivalent to one-third acre garden or park) within a radius of 200 to 500 feet from the house increased the sales price of the house by approximately 1.5 percent" (Pincetl, Wolch, Wilson, \& Longcore, 2003, cited in Been \& Voicu, 2006, pp. 6-7). The findings in LA are in accord with Been and Voicu's study of community gardens in New York, where not only are gardens "likely to generate significant and sustained benefits in poorer neighborhoods" but also that "five years after the garden opens, the impact is even larger: 9.5 percentage points or $\$ 8,405$ " between properties next to gardens and comparable ones outside the 1,000-foot radius ring (ibid, p. 23).

Tranel \& Handlin (2006, p. 151) use census data from 1990 and 2000 and GIS for 3-block radii around 53 community gardens in St. Louis, finding that "Garden Impact Areas [GIAs] improved in indicators of resident quality of life and neighborhood conditions." Their research showed that "GIAs retained a higher percentage of their 1990 population over the decade, increased the rate of home ownership on average by over $50 \%$, and retained a high percentage of residents who lived in the area long enough to pay off their mortgage" (ibid, p. 164). More conceptually, they suggest that:

Community development though community gardening appears to address the structural [flaws] in redevelopment programs noted over twenty years ago by Meehan. It is not a "trickledown" investment strategy in expensive "bricks and mortar" projects but a direct investment in neighborhoods, and the investment is as much in the development of the residents as it is in the physical improvements (ibid, pp. 164-165).

Bringing additional significance to the above studies are findings from the 2002 Agricultural Census that highlight an emerging trend of immigrant farms and immigrant-based urban agriculture in the past few decades (Gottlieb, 2006b; Senate Special Task Force, 1992), as well as a recent study revealing that Latinos face the highest risk of hunger among all race/ethnicities in LA County (University of California, Los Angeles, 2004). Collectively, these reports allude to urban gardening and agriculture's potential to cost-effectively address a multitude of the challenges facing inner-city, poor, and minority communities today (see Saldivar-Tanaka \& Krasny, 2004).

\section{Improvements in Physical and Quality-of-Life Conditions in South LA as a Result of the SCF}

If the SCF community garden was granted to the South LA community to ameliorate environmental injustices the community was facing circa 1992, how had such conditions changed in 2006? While the farm met its primary purpose of feeding the farmers' families, Tranel and Handlin's suggestion that urban gardening can also play a significant role in improving the quality of life of the residents finds substantiation in the case study of SCF. Here, in addition to relieving food insecurity, the farm provided a much needed community development venue for this burgeoning ethnic landscape, or "ethnoscape" that otherwise had no outlet in this barren industrial area. The farm provided a medium to preserve and recreate community traditions of agriculture and heirloom seeds, survival strategies of indigenous cultures that had sustained them through five hundred years of physical and cultural exploitation, as well as the farmers' ability to pass on their living traditions to their children-many of whom could "tell the names of every plant on the land in an indigenous language, in English and in Spanish" (Radford \& Santos, 
2006). It was an alternative for youth from gangs and drugs, and a place where the elderly could contribute in a substantial way to the community. The community's formal decision-making structure-planning, political outreach, presence at City Hall-turned the farm into a "democracy workshop" (Kuipers, 2005), offering critical tools to participants that even now continue to be applied in the ongoing struggle for the recovery of the SCF site and the promotion of larger EJ goals in the region. As Rufina Juárez, SCF elected representative, commented, "there are families here that have never taken a role in terms of participating anywhere, and now they know how to go to City Council, they know who their representatives are" (cited in Hoffman, 2006). In effect, it provided a physical, social, economic, and cultural forum for members of the community to realize their potential as both individuals and as a collective.

Aside from its benefits to South LA, the farm has also tremendous educational value for others. Even after its destruction in July 2006, it continues to offer valuable conditions for theoretical reflection, empirical testing, policy analysis, and proposal making to students and researchers interested in matters of social and health policy making, social work, urban planning and design, community and economic development, urban studies, cultural sociology and anthropology, and Latina/o, Latin American, and American Studies. ${ }^{6}$

\section{SCF: THE RISE AND FALL OF AN URBAN FARM}

\section{The Legal Dilemmas}

After providing analytical frameworks to examine the case, this section examines the political and legal history of the site of the farm and identifies the primary stakeholders. The site was acquired in the mid 1980s by the City of LA through eminent domain from Alameda-Barbara Investment Company (ABIC) — whose major investor was real estate lawyer Ralph Horowitz- to build a trash incinerator. In opposition to this use, community members created a nonprofit organization called the Concerned Citizens of South Central Los Angeles (CCSCLA), and demanded public hearings and a health-risk assessment of the project. In 1987, the City Council and then Mayor Thomas Bradley agreed to abandon this plan, as evidence emerged of environmental injustice in the inequitable distribution of such facilities throughout its jurisdiction. Subsequently, during the 1992 civil unrest, many of the neighborhood grocery and retail stores were burnt down, leaving the area devoid of basic amenities. In an effort to mitigate this widespread dearth of resources and opportunity, the Agriculture Department and Rebuild LA announced plans to provide up to $\$ 2.75$ million in matching funds for grants to establish and maintain urban gardens and provide job training (Weinstein, 1992). The 41st and Alameda Street site was one of 10 such garden projects planned across South LA (Feldman, 1993). This socially motivated rationale for the granting of this land use to the community in 1992 is critical to the argument for the farm's preservation presented in this article.

Meanwhile, the city worked to keep selected high-risk investment in the area profitable through subsidization. The Alameda Corridor-a rail and truck line from the Port of Los Angeles through South LA and the city of Vernon-was one such project into which LA City invested 2.4 billion in the 1990s, significantly raising the exchange value of the farm's 41st and Alameda site. However, by directing the investment capital away from the rest of South LA, and redirecting government money earmarked for "rehabilitation" to industry and developers, residential neighborhoods were left in devastation. Prior to the 1992 rebellion, for example, plans for the site included low-income townhouses. Instead, the city decided to sell the land to the Harbor Department for the Alameda Corridor rail project in 1994 for \$13.3 millions, roughly double what was proposed to the affordable housing developers and triple the amount the city had paid to ABIC. 
In 1995, ABIC—now the Libaw-Horowitz Investment Company (LHIC)—expressed a renewed interest in the property, and just a year later, the city and LHIC fixed a sale amount at $\$ 5.2$ million. However, lacking City Council approval, the sale was not executed (Hecht, 2006). Furthermore, the land now belonged to the Harbor Department, an independent agency, not the city. In 2002, after a lapse of 6 years, Horowitz sued over the sale to the Harbor Department, arguing a breach of agreement and a violation of his right of first refusal, that is, the right to buy back the land since it was not being utilized for the proposed "public good" use for which it was originally taken in the 1980s - the trash incinerator. However, while a purchase agreement had been executed with Horowitz, the terms of the agreement made it contingent on City Council approval. Furthermore, even with approval, Horowitz only had the right to negotiate and make an offer (Stormer, 2006). The judge presiding over this case ruled against Horowitz three times. Finally, in June of 2003, an out-of-court settlement occurred between Horowitz and City Attorney Rocky Delgadillo for the amount of $\$ 5.05$ millions, or approximately as much as the land was worth during the eminent domain process in the late 1980s, almost two decades before, and definitely before the Alameda Corridor project had been built and its impact felt in real estate prices (Kuipers, 2005). Despite prompting significant public scrutiny, this settlement was subsequently approved by the LA City Council in a closed session, securing the dismissal of the LHIC suit and the donation of 2.7 acres of the land to the city for recreation purposes. The land was transferred to Horowitz in December of 2003, and the LA Regional Foodbank delivered a notice of permit termination to the farmers by February 29, 2004. It is at this time that the families organized as the South Central Farmers Feeding Families (SC Farmers) sought legal counsel, and filed a complaint against LHIC, the City, and the LA Regional Foodbank. This complaint resulted in the win of a temporary restraining order that aimed to prevent the demolition of the garden until the suit was adjudicated.

\section{The Plight of the Legally Disenfranchised}

The restraining order protecting the farm, however, was reversed on appeal from the City and LHIC defendants. In October 2005, the California Supreme Court refused to hear the farmers' lawsuit. Then, on April 22, 2006, the Trust for Public Land, along with Mayor Villaraigosa's office, negotiated a 30-day buy option from developer Ralph Horowitz contingent on the City's matching a \$5-million donation from a private foundation. At Mayor Antonio Villaraigosa's urging, the working-class community connected to the farm began fundraising through individual contributions, effectively bearing the burden of 11-plus million dollars of profit from this land in 3 years for the real estate developer. By 2006, Horowitz was seeking \$16.3 million for the property, a value more than three times the 1986 eminent domain valuation, and $\$ 11.25$ million more than he had paid when he purchased it from the LA Harbor Department merely 3 years before, in 2003. Several SC Farmers and supporters we interviewed considered that Horowitz had received a blatant subsidy from the city when he rebought the land below market value in 2003, a deal that in their views had hurt taxpayers. Conversely, Horowitz described the use of the land for a permanent garden as a financial waste: "Taxpayers are giving up lots and lots and lots of money for these 300 farmers" (Gottlieb, 2006b).

According to the Los Angeles Superior Court, after the buy option period expired, the developer acquired the legal right to deploy the Los Angeles Sheriff's Department to remove farmers and supporters (SCF, 2006). In expectation, the farmers organized events and civil disobedience trainings to resist eviction. In early June 2006, there was a hopeful break in the case: the Trust of Public Land entered into negotiations with the Annenberg Foundation, which made an offer of $\$ 10$ million in cash and an agreement to finance the remaining \$6 million needed to purchase the property. Horowitz, however, rejected the offer (for a price that he himself had defined) 
and demanded the farmers' removal. On June 13, 2006 at 5 a.m., 65 helmeted deputies of the Sheriffs' Department's Civil Management Unit moved into the farm, with the LAPD and Los Angeles Fire Department assisting in a show of force. Most of the occupants of the land left on their own, some practiced civil disobedience, and, according to The Los Angeles Times, more than 40 protesters were arrested (Becerra, Garvey, \& Hymon, 2006). Horowitz in turn sued the farmers, 350 poor families, for almost a million dollars, claiming that they were abusing the legal system (Philpott, 2006). Prevented from re-entering the fenced-off farm from June 13 onward, farmers and supporters kept vigils around the dying garden for days, planting crops and flowers around the perimeter of the site in symbolic expression of hope and protest. On July 5, the farm was bulldozed over, including many trees, in front of the traumatized farming families and friends.

\section{The Mayor's Lament}

A few hours after the evictions, Villaraigosa spoke with Horowitz on the telephone and reiterated his support for the Annenberg Foundation's \$16 million offer. According to multiple sources (personal informants and media accounts), however, at that point Horowitz expressed that he felt personally vilified by the farmers, was angered by their tactics, and would not sell to them for any price. The Mayor lamented the outcome, revealing his torn convictions:

I understand a businessman's need to invest and make a profit ... But I also believe that we are called upon by a sense of community and civic duty to do the just and right thing. I had hoped that the landowner would have heeded that call (Villaraigosa, quoted in Hopkins, 2006).

Saving the SCF, however, would have been within Mayor Villaraigosa's reach and stated vision for Los Angeles. During his mayoral campaign, Villaraigosa had pledged to transform Los Angeles "into the cleanest, greenest big City in America," and had offered to "build more parks, particularly in the most underserved neighborhoods" (Villaraigosa, 2005). Afterward, Villaraigosa, who had used the SCF for campaign photo opportunities and had offered the farmers his support, was elected in 2005 by a celebrated alliance of White liberals and Latinos, and with about half of the City's African-American vote. The mostly Mexican and Central American farmers, who had contested the farm's sale since 2003, had new hope. After being elected, Villaraigosa often reassured the farmers behind the scenes. However, he did not endorse their efforts publicly until very late in the process. Additionally, when Villaraigosa offered to fundraise in order to buy back the land from Horowitz, he arguably could have tapped into the profit the city had made from the sale of the site to the Harbor Department in 1994 ( $\$ 13.3$ million), as well as the money it had made in the closed-session settlement with Horowitz in 2003 (\$5.2 million). Furthermore, the Mayor, the City Attorney, and the City Council could have used money from the $\$ 129$ million in QUIMBY fees collected from developers for parks and recreation to save the South Central Farm, as reasoned by City Controller Laura Chick (Los Angeles Independent Media Center, 2008).

However, these decisions were not made, but not for lack of public pressure. Besides physically and legally resisting the eviction, the SC Farmers created over the 3-year struggle a strong set of alliances, and diverse methods of protest. Protest tactics included rallies and marches; public input at City Council meetings; pickets to the Mayor and other public figures at public appearances; press conferences, Web sites, e-mails; panels, concerts, religious ceremonies and vigils; health, arts and crafts, and anti-consumption fairs; produce markets, and more. Local, national, and international supporters included peace and environmental activists (e.g., the Interfaith Committee for Peace \& Justice and Trust for Public Land), politicians (Ralph Nader, Maxine Waters, and Dennis Kucinich), philanthropists (the Annenberg Foundation), actors, singers, and other 
cultural performers, professors, students, religious leaders, and multifaith coalitions. A creative proposition accompanied the political pressure: place the land in a community land trust and reopen the farm as a multipurpose park for the region as well as the neighborhood.

After the eviction, farmers and supporters retained the hope that they were going to recover the land in a class-action suit alleging that the 2003 sale of the land to Horowitz should be nullified on grounds that there was no prior public notice of the transaction, that there was a lack of transparency in the sale, and that taxpayers were unduly hurt by the below-market price given to Horowitz. The farmers were also prepared to demonstrate how the farm provided multidimensional public benefits that outweighed the benefits of other potential uses in the site, particularly that of a warehouse, the alleged use Horowitz wanted in the site. ${ }^{7}$ Proceedings began on July 12, 2006, presided over by Judge Helen Bendix. Despite Horowitz's attempt to withhold documentation of his 2003 purchase deal, evidence disclosed that the property was appraised at $\$ 19$ per square foot, but was sold to Horowitz at \$10 per square foot. Bendix, however, ruled that the sale was not unlawful, and the farmers' arguments were rejected on July 27, 2006. According to Tezozomoc, elected representative of the farmers, Judge Bendix was a prohibitive factor in the trial: "[W]e were not allowed to offer counter-evidence that there was more public benefit to be gained from a farm" (Tezozomoc, cited in Kuipers, 2006a). He further asserted in our interview other ways in which treatment at the trial was deferential to Horowitz and discriminatory to the farmers, who were not allotted the same opportunities to provide evidences or offer testimony.

As of this writing, the city is advancing plans for a trucking center for Forever 21, a women's clothing manufacturer and retailer which has strong ties to Mayor Villaraigosa. The mayor received \$1.3 million from Forever 21 during 2006-2007 for some of his projects, and at least 3 council members, including Councilwoman Jan Perry and two Latinos, are also on record as receiving contributions from Forever 21. In addition, the company's founder is a registered City Hall lobbyist, and its Senior Vice President was appointed by the mayor to the city's Industrial Development Authority. Hence, the SC Farmers, citing a conflict of interest by the mayor and other city officials when they negotiated with Horowitz, have not desisted in their legal efforts, demanding that California's State Attorney General investigate the sale of the site by Los Angeles city officials to Horowitz (Los Angeles Independent Media Center, 2008; Zahniser, 2008).

\section{Political/Racial Overtones and "the Jobs Card"}

It is critical to note that the political and racial overtones of the struggle over this site, while less overt than the financial issues, may have been the more influential factors determining its outcome. Jan Perry, the LA Councilwoman whose 9th District included the farm, was not supportive of its preservation, and actively worked for its removal arguing that the use was not appropriate for the site. She failed to respond to the pleas of the farmers and their legal representatives, and was disrespectfully dismissive when they presented their arguments in City Council meetings. ${ }^{8}$ Councilwoman Perry also happens to be African American, and while publicly supportive of looking into relocation possibilities for the mainly Latino farmers, several of our informants within and outside City Hall considered that she was more responsive to the expectations of her African-American constituents in South Los Angeles. African Americans in the area have long been organized through the previously mentioned Concerned Citizens of South Central Los Angeles, a group that Perry maintained best represented the interests of her constituents. Significantly, the CCSCLA is a politically and economically powerful organization that exerts significant influence in election campaigns and results. Today, in a neighborhood in demographic transition from majority black to majority Hispanic, many African Americans, including members of the CCSCLA (all blacks), perceive the growth of Latina/os in their neighborhood as a threat that displaces them and brings about less access to jobs and services. 
TABLE 1

Racial Composition of the South Central Farm Neighborhood, 1980-2000

\begin{tabular}{lrrrr}
\hline & 1980 & 1990 & $2000^{\ddagger}$ & \multicolumn{1}{c}{ Change } \\
& & & \multicolumn{1}{c}{$(1980-2000)$} \\
\hline Non-Latino Black & 45,625 & 28,811 & 17,093 & $-28,532$ \\
Latino & 39,528 & 89,435 & 104,940 & 65,412 \\
Other & 2,444 & 2,766 & 2,860 & 416 \\
Total & 87,597 & 121,012 & 124,893 & 37,296 \\
\hline
\end{tabular}

Source: U.S. Census Bureau, 1980 STF 1, Table 37, 1990 STF 1, Table P10, 2000 STF 1, Tables P8, P10.

†The category "Latino" refers to those who identified as Hispanic, Latino, or as having Spanish origin.

¥The category "Non-Latino Black" includes those who identified as Black or African American alone, or in combination with one or more other races.

TABLE 2

Share of Population by Race in the South Central Farm Neighborhood, 1980-2000

\begin{tabular}{lrrrr}
\hline & 1980 & 1990 & $2000^{\ddagger}$ & $\begin{array}{c}\text { Change } \\
(1980-2000)\end{array}$ \\
\hline Non-Latino Black & 52 & 24 & 14 & -38.4 \\
Latino $^{\dagger}$ & 45 & 74 & 84 & 38.9 \\
Other & 3 & 2 & 2 & -0.50 \\
Total & 100 & 100 & 100 & - \\
\hline
\end{tabular}

Source: U.S. Census Bureau, 1980 STF 1, Table 37, 1990 STF 1, Table P10, 2000 STF 1, Tables P8, P10.

†The category "Latino" refers to those who identified as Hispanic, Latino, or as having Spanish origin.

†The category "Non-Latino Black" includes those who identified as Black or African American alone, or in combination with one or more other races.

Table 1 shows how racial composition has changed over the three decades in the area of focus as a whole, across all census tracts. While the non-Latino Black population saw a decrease of nearly a third between 1980 and 2000, the Latino population did the reverse, almost tripling in number, with an astonishing 65,000-person increase between 1980 and 2000. Between the loss of non-Latino Blacks, and the growth in Latinos, the SCF neighborhood experienced a net increase of 37,000 people by the year 2000 . Table 2 shows each race or ethnicity in proportion to the total population and each other. While blacks and Latinos were nearly equal in population in 1980, a significant shift occurred in 1990, with blacks dropping down to only $24 \%$ of the population, and Latinos growing to occupy 74\%. Ultimately, the change between 1990 and 2000 was still significant but less dramatic, with another $10 \%$ loss in black population, and an equal amount of growth for Latinos. ${ }^{9}$

According to an anonymous source from City Hall, Perry was astute at playing "the jobs card" in order to defend her development decisions for the 9th District in City Hall. The importance of keeping and attracting jobs to this area is foremost on many residents' minds, and therefore an easy means of shaping public opinion toward a particular issue. In the case of the SCF, "the jobs card" could strategically have been used to help cover any racist and/or xenophobic motivations for Perry's energetic work in disfavor of the majority Latina/o unauthorized immigrant farmers who could not vote, despite the negligible impact of a potential warehouse in job creation.

Other racial overtones of the case allegedly precipitated the progress of the story to date. At one point, copies of an Internet article calling Horowitz part of a Los Angeles "Jewish development mafia" circulated through the corridors of City Hall, and anti-Semitic epithets against him were used in a Web site. Enraged, Horowitz attributed them to the farmers, although 
they claimed they were the makings of groups with no affiliation with them and that it was antithetical to their organization to be discriminatory. Whatever the case, Horowitz justified his unwillingness to sell the land to the farmers, regardless of the price offered, on his allegedly feeling discriminated against by them (Radford \& Santos, 2006). A city official who spoke on condition of anonymity stated that this was just an excuse for Horowitz, who as a developer keen on working in Council District 9 and with other real estate deals in the pipeline there, was not going to sell this land to the city or to the farmers without Perry's approval. And Perry was not approving.

Other factors added to the disenfranchisement of the SC Farmers. Despite their relentless lobbying at City Hall and the broad-based social support for their cause, the farmers could not gain council members' sympathy, even among Latino representatives. Several anonymous sources explained this as being a part of a "pay-to-play" type of politics that pervades LA City Hall. Within this tradition, council members avoid confronting controversial agendas occurring in other district jurisdictions, so that the favor is returned when the time comes for them to pursue the same in their own districts. Within this tradition, no council member wished to pay the political price of siding with the SC Farmers against council member Perry's will.

The 22-year-old political saga continues. In 2008, the city's Planning Department approved a study on behalf of the Forever 21 distribution center which claimed that the 635,000 square-foot project, with diesel-spewing big rigs making numerous daily trips, would have no environmental impact on local residents, schools, or a recreational area planned to abut the warehouse site. The South Central Farm Support Committee is leading a community challenge, with over 1,700 complainants as well as reports objecting to the construction from the South Coast Air Management Quality Board, the Regional Comprehensive Planning Task Force, the National Resources Defense Council, Progressive Democrats of Los Angeles, the Center for Biological Diversity, Communities for a Better Environment, and the Acequia Institute. A hundred area residents and farmers attended a July hearing and induced the Planning Department's Deputy Advisory Board to reconsider its determination and to demand a more thorough environmental report, still pending (Los Angeles Independent Media Center, 2008; Zahniser, 2008). Meanwhile, Forever 21 representatives have explicitly threatened to leave Los Angeles, taking their manufacturing jobs with them, if they do not find a large site soon. The YWCA's Job Corps program is negotiating with the company to try to make sure it would hire local residents and pay them living wages. Detractors, however, think the project would only create "dead-end jobs" (Zahniser, 2008).

As it is easy to appreciate, the history of the legal procedures, rulings, transfers, and restraining orders regarding the farm is long and complicated, and constitutes a revealing demonstration of the conflict created by the gap between the prevalent capitalist legal ideology and its uneasy interaction with the "insistent demands of various dissidents" (Tigar, 2000). Further details of this ongoing legal saga will not be discussed here. However, the story provides sufficient grounds for understanding the social context of this legal struggle, problematizing the current system of law application, and arguing that the law is usually interpreted and deployed according to biased sociological and extrajurisprudential factors such as class, race, cultural "centrality," language fluency, and power of voting and decision making (Black, 1977).

\section{SCF: THE FUTURE OF RESISTANCE}

While the physical site of the SCF may be permanently lost for a communal use, the farmers' past and present actions continue to provide lessons for those interested in the future of the just and equitable city. By combining environmental concerns and social and racial justice, EJ leaders such as the South Central Farmers are being recognized as having greater mobilizing and coalitionbuilding potential than Smart Growth, New Urbanist, or New Regionalist advocates (Rast, 2006, 
p. 254): "Environmental justice addresses the weakest link in the smart growth movement-the need for solutions to the problem of urban poverty. Smart growth rhetoric addresses such equity concerns, but its political base of middle class whites limits its effectiveness as a vehicle for helping poor people." Rast stresses that it is critical "to frame the question of regionalism in language that resonates with people of color while persuading middle-class suburbanites that efforts to promote regional economic prosperity and improve quality of life for the middle class hinge in part on the fate of the inner city" (ibid, p. 261). However, Rast's proposition only addresses one side of the challenge, running the risk of perpetuating the very elitism that the author identifies as a problem in the smart growth, new urbanist, and new regionalist movements. A critical part of making this dialogue authentic is making it multidirectional. While white middleclass suburbanites should strive to expand inclusion of non-white lower-income urbanites, they should also understand and respond to the latter's own initiated calls for solidarity and leadership toward different conceptions of fairer and more sustainable regionalism. Notably, in the case of the SCF, it was the SC Farmers, representing non-white lower-income urbanites, who were heading the regional, and even international, call for environmental justice. Unfortunately, the potential strength of the multiethnic, multiclass coalition representative of the SCF struggle did not materialize soon enough and to the extent necessary to save the farm from destruction. Despite this flaw, SC Farmers members signal the burgeoning growth of minority-in this case Latina/o-EJ activism, a movement identified as a "greening" of Latino politics, or a "browning" of environmentalism (George, 2006).

Second, the SC Farmers and supporters have pledged to continue working on realizing a vision of a healthy, livable city for LA. In an interview with Grist, SCF representative Tezozomoc said, "There's a bigger thing we're trying to get at. Livable cities require commons. Our principal stand is about making our cities more livable. With peak oil and energy problems, we're going to need local solutions like this" (Mark, 2006). Currently, the farmers' work continues in the form of the South Central Farmers Health and Education Fund, a nonprofit organization dedicated to grassroots health education through urban agriculture, with the mission of "seeking to restore the traditional place of local organically grown fruits and vegetables in the diets and lifestyles of low income ethnic minority populations in the inner city" (Tezozomoc, 2006). Additionally, the farmers have begun farming on leased land in the Central Valley, 2 hours away from LA, and have launched a "Growing Food for your Hood" program that features a distribution network offering weekly delivery of produce to community members (Kuipers, 2006b). The original farm site continues to act as a base for the community. Not only have the farmers set up their organization's office in a building across the street from the destroyed farm, but a monthly farmers' market is also hosted on an adjacent site and at different produce markets throughout the city. Work on local, national, and international outreach and networking also continues. Recent activities have included actions in solidarity with Korean farmers, the crafting of resolutions for the National Latino Congreso 2006, a delegation to a United Nations forum on indigenous rights, and a grant acquisition from UCLA CORICA Cancer prevention program to do community-based research on the need for access to fresh produce in the community (Tezozomoc, 2006).

\section{CONCLUDING WORDS}

The SCF may be lost, but the struggle to defend, maintain, and expand the use value of some key irreplaceable spaces in Los Angeles and other U.S. cities remains, and the farmers have positioned themselves at the forefront of this endeavor. In order to defend the right to the just city, nonetheless, decision makers in Los Angeles — and elsewhere-need to be both aware of conditions that militate against the use value of extraordinary spaces such as the SCF, and committed to redress them. 
The legal problems faced by the South Central Farmers were neither unique nor insurmountable. Clearly, the farmers were inherently disadvantaged within a sociolegal framework, created and maintained for the purposes of preserving and perpetuating the sociocultural status quo and legitimizing capitalist modes of production, including property rights and land development processes. From this critical perspective, the farmers had distinct disadvantages - aside from any jurisprudential challenges-rooted in their very skin color and nonestablishment culture. The legal "game" was not one designed to afford due process to people like them, and it showed that it was not to this game that they could turn for essential protection and empowerment. Los Angeles provides us with many illustrative historical examples of this biased modus operandi, including the infamous displacement of a disadvantaged community from Chavez Ravine in the 1950s to build the Dodgers Stadium. The city, however, also offers The Cornfields and Taylor Yards, recently created state parks, as examples that another more sustainable and equitable governance dynamic is possible (Lejano \& Taufen Wessels, 2006).

Anybody interested in this agenda needs to aggressively forge multiclass and multiracial coalitions. By creating such coalitions, poor people of color may overcome the built-in biases of the constrictive sociolegal system and garner greater political support for their goals. Similarly, white middle- and upper-class people may broaden their base of support and traction, and expand their conception of and opportunities to accomplish equitable development. The SCF shows that there is an urgent need for political leadership and will and social mobilization to enact both the repudiation of the "post-justice city" and explore alternative models of development and conviviality in Los Angeles.

While Mayor Villaraigosa and others did not step up to the challenge to save the SCF, some of his valid campaign ideas remain to be implemented (Villaraigosa, 2005): use surplus city property to create more neighborhood parks and community gardens with vacant lots from the city's backlog of 2,400 surplus properties; pursue open-space funding from federal, state and other sources; expand shared use of school playgrounds and parks; and acquire new open space by working with neighborhood land trusts and other nonprofits. Garden advocates point to other ways in the which the city could better demonstrate its commitment, including the financial support of the Los Angeles Neighborhood Land Trust, the creation of tax incentive programs, a green space creation requirement as a condition of approval for development, and setting goals to establish a community garden in every council or neighborhood council jurisdiction (Gottlieb, 2006a).

Patricia Preciado Martin's story “The Journey," quoted at the beginning of this article, expressed the hope of a Latina victim of an urban renewal project: "The flowers [cracking through her bulldozed house] always win," she resolutely told her niece. In the South Central Farm case, crops and flowers literally sprouted in and around the SCF amid the debris from the destruction of the farm. They symbolize both that the structures of domination that perpetuate environmental injustices in the city persist, and that their victims would not abandon hope and resistance. SC Farmer Alberto Tlatoa poetically stated it for a group of students visiting the destroyed farm in August 2006: "Like the nopal [cactus plant] pushing through the concrete, the spirit of the land and the people refuses to be bulldozed and concreted over."

ACKNOWLEDGEMENTS: We acknowledge the support of the Urban Initiative and the Center for Religious and Civic Life at USC for this research. We are thankful to Tezomomoc, Rufina Juarez, Alberto Tlatoa, Fernando Flores, and other members of the South Central Farmers Feeding Families for their generosity in sharing with us their space, their struggle, and their knowledge. We also appreciate the generosity of all the people interviewed for this article and acknowledge the efforts of Planners Network's USC Chapter's members for their efforts in raising awareness of this struggle and inspiring many to get involved. We acknowledge, in particular, Jason Neville who aptly assisted us through this research and provided helpful comments. 


\section{ENDNOTES}

1 Martin's "The Journey" is a story about the U.S. settlement of Arizona and the struggle of the Hispanic culture that it aimed to erase. It ends with the narrator discovering a flower springing through a crack in the asphalt covering her aunt's destroyed house (cited in Brady, 2002).

2 This area was previously known as South Central LA. Its name was changed in April 2003 to South LA by a unanimous vote of the LA City Council in a marketing attempt to dispel the negative connotations of crime, drugs, and gangs associated with it. Councilwoman Jan Perry wrote the motion to change the name. Keeping "South Central" in both the names of their farm and organization (South Central Farm and South Central Farmers) is in this context an act of resistance by the farmers.

3 As determined by the Emergency Food Assistance Program (TEFAP) (Darren Hoffman, personal communication, September 3, 2006). TEFAP is a federal program that works in conjunction with the U.S. Department of Agriculture. It helps supplement the diets of low-income needy persons, including elderly people, by providing them with emergency food and nutrition assistance.

4 Figure 2 demonstrates that change in the area since 1980 has been significant, with more than half of the tracts seeing a $200-399 \%$ change in Latina/o population, with five tracts experiencing greater than $400 \%$ growth. For analysis of trends over time within specific tracts, eight tracts in 1990 that were split into multiple tracts in 2000 were converted back to their 1990 boundaries. The time frame and boundaries for the study were chosen with the intention of tracking demographic change in the area around the site since its initial taking through eminent domain. The boundaries chosen approximate the "area of concentration" identified by the CCSCLA (Santa Monica Freeway to the North, the Harbor Freeway to the West, Slauson Avenue to the South and Alameda to the East), and encompass census tracts within 2 miles of the site. This allowed us to examine how the racial and ethnic make-up of the organization's constituents, the "neighborhood" around SCF, has changed since its inception.

5 The social upheaval of 1992 Los Angeles is more commonly referred to as the 1992 riots in popular media, given the fact that it involved the damaging of property and other acts of violence. However, the term rebellion has been preferred by many analysts and community members who considered that a majority of participants in the street activities were rebelling against systemic conditions of racism, poverty, and police brutality prevalent in poor and minority neighborhoods of Los Angeles that had received their ultimate, blatant expression in the acquittal of four police officers accused of brutalizing Rodney King, an African American (see Costa Vargas, 2004).

6 As an example, the authors of this article led a day-long community service workshop to freshman college students in August 19, 2006, at the SCF site, in collaboration with the South Central Farmers.

7 In fact, the company Forever 21 has advanced a project for a trucking and distribution center on the site. There are many warehouses in the area, some vacant and underutilized. Meanwhile, there is an appreciable deficit of parks and recreational services (Sister et al., 2007).

8 There is video-taped evidence of Perry checking her e-mail and performing other distracting activities while the farmers and supporters spoke at City Council meetings.

9 In South LA, the black population was $55.0 \%$ in 1990 and $39.8 \%$ in 2000. In comparison, LA City was $14.0 \%$ blacks in 1990 and $11.2 \%$ in 2000. In South LA, the Latino population was $45.5 \%$ in 1990 and $58.0 \%$ in 2000. In comparison, LA City was $39.9 \%$ Latino in 1990 and $46.5 \%$ in 2000 . There was, then, a $24.5 \%$ decline in black population from 1990 in South LA, relative to 14.9\% decline in Los Angeles City, and 6.2\% decline relative to Los Angeles County (Myers, 2002).

\section{REFERENCES}

Adelman, S., \& Foster, K. (n.d.). Critical legal theory: The power of law. Available at http://www.nclg. org.uk/books.htm, accessed February 19, 2007. 
Altheide, D. L. (1996). Qualitative media analysis. Thousand Oaks, CA: Sage Publications.

Altman, A. (1986). Legal realism, critical legal studies, and Dworkin. Philosophy and Public Affairs, 15(3), 205-235.

Baumgartner, M. P. (1999). The social organization of law. London: Academic Press.

Becerra, H., Garvey, M., \& Hymon, S. (2006). L.A. garden shut down; 40 arrested. Los Angeles Times, July 6, B1.

Been, V., \& Voicu, I. (2006). The effect of community gardens on neighboring property values. Marc. Law and Economics Research Paper Series. Working Paper No. 06-09. NYU Center for Law and Economics.

Black, D. (1977). The behavior of law. London: Academic Press.

Brady, M. P. (2002). Extinct lands, temporal geographies: Chicana literature and the urgency of space. Durham, NC: Duke University Press.

Bullard, R. D. (1994). Unequal environmental protection: Incorporating environmental justice in decision making. In A. M. Finkel \& D. Golding (Eds.), Worst things first? The debate over risk-based national environmental priorities. Washington, DC: Resources for the Future.

Bullard, R. D., Johnson, G. S., \& Torres, A. O. (2000). Sprawl city: Race, politics and planning in Atlanta. Washington, DC: Island Press.

Bunge, W. (2001). Author's response: Geography the innocent science. Progress in Human Geography, $25,75-77$.

Costa Vargas, João H. (2004). The Los Angeles Times' coverage of the 1992 rebellion: Still burning matters of race and justice. Ethnicities, 4(2), 209-236.

Cotterill, R. W., \& Franklin, A. W. (1995). The urban grocery store gap. Food Marketing Policy Paper 8. Storrs: Food Marketing Policy Center, University of Connecticut.

Cornell Law School, Law School Legal Information Institute Web (2006). Critical legal theory, critical legal studies: An overview. Available at http://www.law.cornell.edu/wex/index.php/Critical_legal_theory, accessed January 25, 2007.

Curtis, S. (2004). Health and inequality: Geographical perspectives. London: Sage.

Day, K. (2006). Active living and social justice: Planning for physical activity in low-income, black, and Latino communities. Journal of the American Planning Association, 72(1), 88-99.

Dreier, P., Mollenkoph, J., \& Swanstrom, T. (2001). Place matters: Metropolitics for the twenty-first century. Lawrence: University Press of Kansas.

Fainstein, S. (2000). New directions in planning theory. Urban Affairs Review, 35(4), 451-478.

Feldman, M. S. (1994). Strategies for interpreting qualitative data. Thousand Oaks, CA: Sage Publications.

Feldman, P. (1993). Harvest of hope. Los Angeles Times, August 19, B1, B4.

Ford, R. T. (1999). Crossing borders. Available at http://jurist.law.pitt.edu/lawbooks/revapr99.htm\#Ford, accessed February 19, 2007.

George, E. (2006). Browning the green movement. Los Angeles Alternative, September 15.

Gilmore, R. (2004). Golden gulag: Prison, surplus, crisis, and opposition in California, 1982-2000. Berkeley: University of California Press.

Gottlieb, R. (2006a, July 13). Direct testimony given at Superior Court of the State of California for the County of Los Angeles, Central District.

Gottlieb, R. (2006b). Showdown at South Central farm. The Next American City, 2006/2007 Winter. Available at http://www.americancity.org/article.php?id_article=212, accessed January 15, 2007.

Harvard Bridge Project (n.d.). Legal theory: Critical theory overview. Available at http://cyber.law. harvard.edu/bridge/CriticalTheory/criticall.htm, accessed February 19, 2007.

Harvey, D. (2003). Debates and developments: The right to the city. International Journal of Urban and Regional Research, 27(4), 939-941.

Hecht, J. (2006). The future at war with the past: While South Central's urban farmers face eviction, peak oil threatens global food supply. From The Wilderness. Available at http://www.fromthewilderness. com/cgi-bin/MasterPFP.cgi?doc=http/, accessed October 2, 2006.

Heynen, N., Perkins, H., \& Roy, P. (2006). The political ecology of uneven urban green space: The impact of political economy on race and ethnicity in producing environmental inequality in Milwaukee. Urban Affairs Review, 42(1), 3-25.

Hoffman, J. (2006). LA urban farmers fight for community garden. New Standard. Available at http://newstandardnews.net/content/index.cfm/items/3027, accessed October 5, 2006.

Holstein, J. A., \& Gubrium, J. F. (1995). The active interview. Thousand Oaks, CA: Sage Publications. 
Hopkins, B. (2006). The end for South Central Farm? LA Daily News. Available at http://www.dailynews. com/news/ci_3933788, accessed August 7, 2006.

Institute of Medicine (1999). Toward environmental justice: Research, education, and health policy needs. Committee on Environmental Justice, Health Sciences Policy Program, Health Sciences Section, Institute of Medicine. Washington, DC: National Academies Press.

Irazábal, C. (2006). Open letter to Mayor Antonio Villarraigosa. From the Wilderness. Available at www.fromthewilderness.com/pdf/SCF_Mayor.pdf, accessed August 20, 2006.

Irazábal, C. (2008). Introduction: Citizenship, democracy and public space in Latin America. In C. Irazábal (Ed.), Ordinary places, extraordinary events: Citizenship, democracy and public space in Latin America. London: Routledge.

Kirk, J., \& Miller, M. (1985). Reliability and validity in qualitative research. Thousand Oaks, CA: Sage Publications.

Kuipers, D. (2005). Trouble in the garden. LA City Beat. Available at www.lacitybeat.com.

Kuipers, D. (2006a). An (almost) done deal: South Central farmers lose a court challenge to hold on to their 14acre garden. South Central Farmers. Available at http://www.southcentralfarmers.com, accessed August $13,2006$.

Kuipers, D. (2006b). Growing food for your hood. LA City Beat, December 28. Accessed January 28, 2007 at http://www.lacitybeat.com/cms/story/detail/growing_food_for_your_hood/4794/.

Kuo, F. E., \& Sullivan, W. C. (2001). Environment and crime in the inner city: Does vegetation reduce crime? Environment and Behavior, 33, 343-367.

Lefebvre, H. (1968). Le droit à la ville. Paris: Anthopos.

Lefebvre, H. (1996). In E. Kofman (Ed.), Writings on cities. Oxford: Blackwell.

Lejano, R., \& Taufen Wessells, A. (2006). Community and economic development: Seeking common ground in discourse and in practice. Urban Studies, 43(9), 1469-1489.

Los Angeles Independent Media Center (2008, August 18). South Central Farmers demand ethics investigation of local officials. Accessed December 2, 2008 at http://la.indymedia.org/news/2008/08/219613.php.

Los Angeles Times (2006, March 11). Los Angeles Gothic. Los Angeles Times, Editorial.

MacLeod, G. (n.d.). Citizenship in the 'post-justice' city. Geography of Leisure and Tourism Research Group, Geographies of Citizenship, Royal Geographical Society, with the Institute of British Geographers. Available at http://www.exeter.ac.uk/geography/tourism/gltrg/Events/London/citizenship.html, accessed August 22, 2006.

Mari Gallagher Research \& Consulting Group (2006). Examining the impact of food deserts on public health in Chicago.

Mari Gallagher Research \& Consulting Group (2007a). Examining the impact of food deserts on public health in Detroit.

Mari Gallagher Research \& Consulting Group (2007b). Women and children last (in the food desert).

Mark, J. (2006). Could the battle for South Central farm be coming to a close? Grist. Available at http://www. grist.org/news/maindish/2006/06/09/mark/, accessed October 20, 2006.

Martin, P. P. (1988). The journey. In T. Diana Rebolledo \& E. S. Rivero (Eds.), Infinite divisions: An anthology of Chicana literature (pp. 167-171). Tucson: University of Arizona Press.

Miraftab, F. (2004). Invented and invited spaces of participation: Neoliberal citizenship and feminists' expanded notion of politics. Wagadu: Journal of Transnational Women's and Gender Studies. Available at http://web.cortland.edu/wagadu/vol1-1toc.html, accessed December 2005.

Miraftab, F., \& Wills, S. (2005). Insurgency and spaces of active citizenship: The story of Western Cape anti-eviction campaign in South Africa. Journal of Planning Education and Research, 25(2), 200217.

Mitchell, D. (2001). Postmodern geographical praxis? The postmodern impulse and the war against the homeless in the post-justice city. In C. Minca (Ed.), Postmodern geography: Theory and praxis (pp. 57-92). Oxford: Blackwell.

Mitchell, D. (2003). The right to the city: Social justice and the fight for public space. New York: Guilford Press.

Morello-Frosch, R. A., Pastor, M., \& Sadd, J. L. (2001). Environmental justice and Southern California's 'riskscape': The distribution of air toxics exposures and health risks among diverse communities. $U r$ ban Affairs Review, 36(4), 551-578. 
Myers, D. (2002). Demographic and housing transitions in South Central Los Angeles, 1990 to 2000, Population Dynamics Research Group, School of Policy, Planning, and Development at University of Southern California. Available at http://www.usc.edu/schools/sppd/research/census2000/, accessed August 15, 2007.

Pastor, M., Bullard, R. D., Boyce, J. K., Fothergill, A., Morello-Frosch, R., \& Wright, B. (2006). In the wake of the storm: Environment, disaster, and race after Katrina. New York: Russell Sage Foundation.

Pastor, M., Gallegos, B., \& Prichard, M. (2005). Tainted justice at the EPA. Los Angeles Times, p. B13.

Peña, D. (2003). The scope of Latino/a environmental studies. Latino Studies, 1, 47-78.

Philpott, T. (2006). Community farming in LA: Neoliberalism at the Garden Gate. Counterpunch. Available at http://www.counterpunch.org/philpott03162006.html, accessed August 13, 2006.

Pincetl, S., Wolch, J., Wilson, J., \& Longcore, T. (2003). Toward a sustainable Los Angeles: A “Nature's Services" approach. Los Angeles: USC Center for Sustainable Cities.

Prevention Institute for the Center for Health Improvement (2002). Nutrition policy profiles: Supermarket access in low-income communities. Available at http://www.preventioninstitute.org/CHI_supermarkets.html, accessed September 20, 2006.

Pulido, L. (2000). Rethinking environmental racism: White privilege and urban development in Southern California. Annals of the Association of American Geographers, 90(1), 12-40.

Purcell, M. (2002). Excavating Lefebvre: The right to the city and its urban politics of the inhabitant. Geojournal, 58(23), 99-108.

Purcell, M. (2005). Review of The right to the city: Social justice and the fight for public space by Mitchell, D. Antipode, 37(1), 199-202.

Radford, L., \& Santos, J. (2006). Race, class and the battle for South Central farm: Seeds of hope, seeds of war. Counterpunch. Available at http://www.counterpunch.org/radford07132006.html, accessed August $13,2006$.

Rast, J. (2006). Environmental justice and the new regionalism. Journal of Planning Education and Research, 25, 249-263.

Saldivar-Tanaka, L., \& Krasny, M. (2004). Culturing community development, neighborhood open space, and civic agriculture: The case of Latino community gardens in New York City. Agriculture and Human Values, $21,399-412$.

Senate Special Task Force on a New Los Angeles (SSTF) (1992). The South Central Los Angeles and Koreatown riots: A study of civil unrest. From Government Documents Department and the Doheny Electronic Resources Center, University of Southern California. Available at http://www.usc.edu/ libraries/archives/Cityinstress/newinit/contents.html, accessed November 5, 2006.

Shaffer, A., \& Gottlieb, R. (2002). 1992 riots; Promises of renewal broken. Los Angeles Times, March 10, p. M1. Sister, C., Wolch, J., Wilson, J., Linder, A., Seymour, M., Byrne, J., \& Swift, J. (2007). The green visions plan for 21st century Southern California. 14. Park and open space resources in the green visions plan area. Los Angeles: University of Southern California GIS Research Laboratory and Center for Sustainable Cities.

South Central Farmers (2006). Available at http://www.southcentralfarmers.com/, accessed August 8, 2006.

Spielman, S. E., Golembeski, C. A., Northridge, M. E., Vaughan, R. D., Swaner, R., Jean-Louis, B., et al. (2006). Interdisciplinary planning for healthier communities: Findings from the Harlem Children's Zone Asthma Initiative. Journal of the American Planning Association, 72(1), 100-108.

Squires, G., \& Kubrin, C. E. (2006). Privileged places: Race, residence, and the structure of opportunity. Boulder, CO: Lynne Rienner.

Stake, R. E. (1995). The art of case study research. Thousand Oaks, CA: Sage Publications.

Stormer, D. (2006). Farmers lawyer. Personal interview. Pasadena, CA, 4 September.

Tezozomoc. (2006). An open letter to Mr. Al Martinez. Available at http://southcentralfarmers.com, accessed November 10, 2006.

Tigar, M. E. (1977). Law and the rise of capitalism. New York: Monthly Review Press.

Tigar, M. E. (2000). Law and the rise of capitalism (2nd ed.). New York: Monthly Review Press.

Tranel, M., \& Handlin, L. (2006). Metromorphosis: Documenting change. Journal of Urban Affairs, 28(2), 151167.

U.S. EPA. (1998). 
University of California Los Angeles, Center for Health Policy Research (2004). Policy brief: Hunger in Los Angeles county affects over 200,000 low-income adults, another 560,000 at risk, UCLA Center for Health Policy Research. Available at http://www.healthpolicy.ucla.edu/pubs/files/hunger_PB_06032004.pdf, accessed October 3, 2006.

Villaraigosa, A. (2005). Mayor Villaraigosa's plan for a greener LA. Available at http://www.southcentralfarmers. com/politicianform.php, accessed August 14, 2006.

Weinstein, H. (1992). \$11.3 million in grants, jobs for LA unveiled riots: The package will pay low-income residents to work in national forests. Funds will also help establish urban gardens. Los Angeles Times, June 26, p. B1.

Yin, R. K. (2002). Case study research: Design and methods (3rd ed.). Thousand Oaks, CA: Sage Publications.

Zahniser, D. (2008). Forever 21 development on South Central Farm site is protested. Los Angeles Times, August 18,1 . 